\title{
REFERENCIAÇÃO METADISCURSIVA NO GÊNERO CARTA PESSOAL NO INTERIOR DO ROMANCE: UM ESTUDO DE CASO
}

\author{
Renato Cabral Rezende *
}

Resumo: Este trabalho pretende discutir a referenciação metadiscursiva como fenômeno inerente ao gênero carta pessoal quando representado no interior de outro gênero discursivo, o romance. A carta pessoal tem como uma de suas características o não esgotamento em um único artefato textual. O gênero possibilita a si próprio uma duração longeva, alimentada pela troca epistolar entre os interactantes. No romance epistolar, a troca de cartas promove a passagem do tempo, a realização de ações e a construção do enredo. O corpus deste trabalho é a obra Relato de um certo oriente, de Milton Hatoum. Analisaremos exemplos de referenciação metadiscursiva de que lança mão a narradora-missivista para informar seu interlocutor, seu irmão, sobre a família de imigrantes libaneses que os adotou. Aponta-se como conclusão que o gênero carta, quando representado no interior de um romance, "exige" a referenciação metadiscursiva na/para condução do enredo e na criação da atmosfera memorialística da obra.

Palavras-chave: Referenciação. Metadiscurso. Gênero epistolar. Romance. Milton Hatoum.

\section{CONSIDERAÇÕES INICIAIS ${ }^{1}$}

Tendo em vista esta edição temática especial da revista Linguagem em [Dis]curso, sobre referenciação, este trabalho tem por objetivo discutir a referenciação metadiscursiva presente no gênero carta pessoal de cunho memorialístico representado em uma obra de ficção, o romance Relato de um certo oriente, de Milton Hatoum².

Discutiremos se a referenciação metadiscursiva não seria um fenômeno linguístico inerente ao gênero discursivo carta pessoal memorialística quando representado no interior de outro gênero discursivo, o romance. Nossa proposta de análise tem embasamento teórico em Mondada (1995), Marcuschi e Koch (1998) e Koch (2002;

\footnotetext{
* Doutor em Linguística pela Universidade Estadual de Campinas - UNICAMP. Professor da FCE da Universidade de Brasília - UnB, Ceilândia. Email: rcabralrezende@yahoo.com.

${ }^{1}$ Este artigo é resultante da tese de doutorado do autor, intitulada Expedientes metadiscursivos na categorização e articulação de práticas comunicativas em Relato de um certo oriente, de Milton Hatoum (processo CNPq n 141963/2005), defendida no IEL-Unicamp, sob orientação da Profa. Dra. Anna Christina Bentes.

${ }^{2}$ Para efeitos práticos, faremos referência à obra apenas por Relato... ao longo deste artigo.
} 
2004) e nos trabalhos presentes em Koch, Morato e Bentes (2005), que, diferentemente da concepção referencialista de referência, segundo a qual a língua diz o mundo, apontando suas entidades, definem a referenciação como processo por meio do qual os sujeitos constroem os objetos de dizer em seu discurso. A referência é uma ação conjunta elaborada pelo(s) sujeito(s) da produção textual de forma que, ao longo do processamento textual, os objetos do dizer não são os objetos do mundo, mas objetos de discurso.

Concernente à referenciação metadiscursiva, este trabalho inserese na esteira de Borillo (1985) e, com o advento dos estudos pragmáticotextuais no campo dos estudos do texto, nos trabalhos de Risso e Jubran (1998), Risso (1999) e Koch (2004), para quem o metadiscurso é investigado a nível ideacional e textual-interativo. Para este conjunto de autoras do quadro teórico textual-interativo da linguística do texto, o metadiscurso é uma dentre outras estratégias de processamento textual.

\section{CONHECENDO O RELATO DE UM CERTO ORIENTE}

O argumento narrativo do Relato... é o retorno da narradorapersonagem ao Amazonas, "depois de tanto tempo no sul" (p. 30), no intuito de "reencontrar Emilie" (p.12), matriarca de uma família de comerciantes libaneses radicados no coração da Amazônia, e, por meio de Emilie, tomar conhecimento de fatos e episódios do passado da família. Filha adotiva dessa família (ela e o irmão, cujos nomes não são revelados aos leitores - ele, de Barcelona, insta-a a retornar a Manaus), seu intuito é aprofundar sua percepção da importância do clã para a constituição e consolidação da identidade individual e social sua e do irmão. Muitos fatos concernentes à história da família irão constituir os núcleos narrativos da "carta que seria a compilação abreviada de uma vida” (p. 166) que a narradora enviará ao irmão, a obra que nós leitores lemos. A obra é composta de oito capítulos apenas.

A estrutura da família libanesa é didaticamente explicada ao leitor logo à página 11 da obra: "Sim, com certeza Emilie já lhe havia contado algo a nosso respeito. A mulher sabia que éramos irmãos e que Emilie nos havia adotado". No total, a família retratada no Relato... é composta por onze "membros biológicos" de três gerações apenas. Os avós, 
Samira e Fadel; seus filhos: Emir, Emílio e Emilie; os filhos desta com um personagem que é denominado apenas como "o pai": Hakim, Samara Délia e os dois gêmeos, cujos nomes não são revelados. E a filhinha surda (cujo pai também não é revelado) de Samara, morta em um violento atropelamento: Soraya Ângela.

Figura 1 - Estrutura genealógica da família-núcleo do Relato de um certo oriente

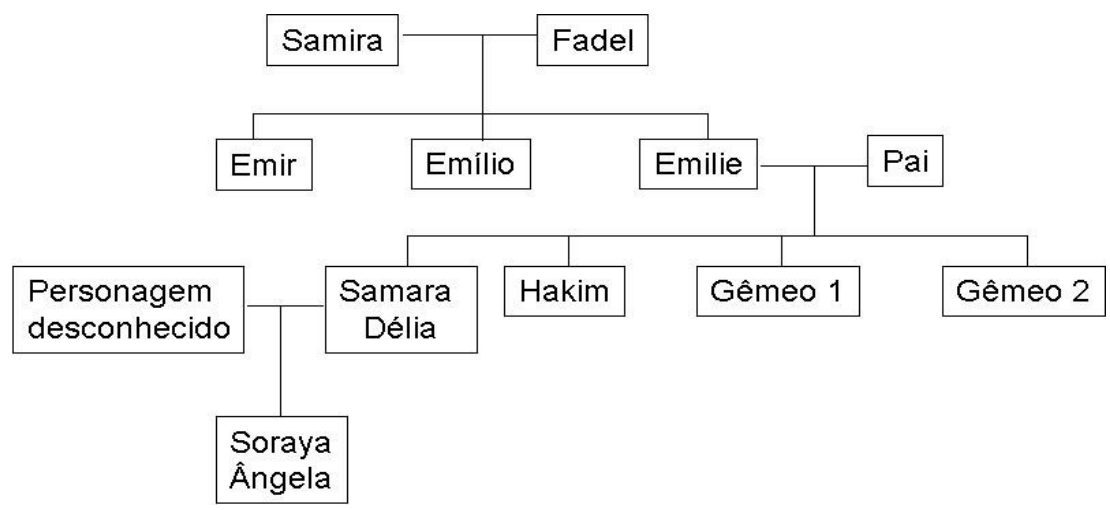

Dentre essas gerações, apenas alguns membros têm sua história, ou, na maioria dos casos, fragmentos dela, relatados. Enquanto Emilio é um irmão apenas mencionado nos capitulos primeiro e sexto, o suicídio de Emir, irmão caçula de Emilie, é tema de um capítulo inteiro (capitulo terceiro). Da mesma forma, os pais de Emilie, Fadel e Samira, são tematizados de forma breve (capitulo segundo) na obra, quando se separam dos filhos para virem a "uma terra que seria o Amazonas" (p. 33), ao passo que o pai da família-núcleo e sua chegada ao Amazonas é tema de todo o capitulo quarto. Assim também se passa com relação ao drama de Samara Délia. Sua gravidez indesejada, e a humilhação dela decorrente, é tematizada ao fim do capitulo quinto. A morte da menina Soraya Ângela ocupa grande parte do capitulo primeiro. Já sobre Hakim, irmão mais velho de Samara, que decide abandonar a família, sabemos mais de sua vida por ele relatar à narradora-personagem muitas passagens e histórias que 
viveu (capitulos segundo e quinto). Apenas de Emilie e sua vida é que temos uma visão mais pormenorizada. Ela é o grande eixo em torno do qual o romance se estrutura.

Mas Emilie morre no dia da chegada da narradora a Manaus. Essa morte impõe à jovem um deslocamento. De ouvinte das memórias daquela que seria possivelmente sua única fonte, a narradora da obra recorrerá a suas memórias e a memórias de terceiros que, sob circunstâncias variadas, se convertem em narradores de episódios que eles próprios viveram, escutaram ou transcreveram. Neste trabalho, porém, vamos nos ater somente às memórias dela e às de seu irmão, de sorte que será ela quem articulará e narrará todas estas memórias, munida de material próprio para tanto: gravador, fitas e seu caderno de anotações.

Em sua obra Discourse in the novel, Bakhtin (2004, p. 262) explica que, no romance, pela sua própria estrutura dialógica, a construção do discurso narrativo se dá por meio da incorporação e articulação à narração do que o autor chama de "tipos básicos de unidades estilísticocomposicionais". A unidade estilístico-composicional basilar do Relato... é a carta pessoal memorialística. O texto final, portanto, é o fechamento de um longo diálogo epistolar entre a narradora e seu irmão. Como então a memória da narradora, e a de seu irmão, são ressignificadas como discurso narrativo na/da obra? De que forma a estratégia de referenciação metadiscursiva atua neste processo, auxiliando a construir o acabamento de estrutura composicional (cf. BAKHTIN, 1984 [1929]) do Relato...?

\section{METADISCURSO COMO ESTRATÉGIA DE PRODUÇÃO TEXTUAL DE SENTIDOS}

Barton e Hall (2000, p. 6) explicam que um dos traços caracterizadores da carta pessoal é o fato de ela constituir-se como um gênero reflexivo: "A referência feita à existência da própria carta é sempre feita no interior dela própria" 3 . Esse componente reflexivo da carta é fundamental na/para a constituição de sua força ilocucionária.

\footnotetext{
${ }^{3}$ No original: "Reference is often made within the letter to the existence of the letter itself".
} 
Segundo os autores, a força ilocucionária específica da carta pessoal advém dos conteúdos que veicula, evidentemente. Mas advém também de sua existência enquanto gênero que, ao fazer referência a si mesmo, resulta também por, neste processo, expor aspectos de sua ancoragem situacional (o escritor da carta está sempre nela presente através da forma "eu", ou mediante uma assinatura ao fim do documento, no "aquiagora" da redação) no intuito de encurtar a distância, seja ela qual for, entre emissor e destinatário. É com base neste princípio que é possível observar como recursos de referenciação metadiscursiva do Relato... atuam para ressignificar memórias individuais em discurso literário narrativo na obra, levando-nos a caracterizá-la como um romance reflexivo.

Segundo Borillo (1985), a reflexividade da linguagem não se esgota no código linguístico ${ }^{4}$. As mais diversas formas de interação pela linguagem propiciam aos sujeitos a possibilidade de refletirem não apenas sobre a língua e o discurso em desenvolvimento, mas sobre sua própria ação comunicativa e os elementos pertencentes ao quadro interacional em que se encontram.

O metadiscurso é uma manifestação da reflexividade da linguagem. É “um discurso centrado no código, mas o código tomado em sentido amplo, remetendo tanto à estrutura da língua enquanto sistema, quanto à sua ativação em situação de comunicação" (BORILLO, 1985, p. 49). O que o caracteriza é o fato de que um dado discurso coloque não apenas a si próprio como objeto de glosa, mas considere todos os demais elementos envolvidos na interação como partes da elaboração discursiva: o próprio ato de enunciação, suas condições enunciativas, as intenções e estratégias discursivas do falante, o pano de fundo conceitual e até mesmo as condições materiais da

\footnotetext{
${ }^{4}$ A noção de reflexividade em linguagem diz respeito ao potencial "meta" que toda língua natural possui. No campo dos estudos linguísticos, em sua definição mais forte ela é associada à "metalinguagem": um sistema próprio interno à língua, cuja função é fazer com que ela, a língua, possa referir-se a si mesma; sistema que concerne fundamentalmente a determinados itens lexicais da língua. Por essa razão, sua manifestação discursiva se constituirá como discurso centrado exclusivamente no código (cf. REY-DEBOVE, 1978, p. 163, apud BORILLO, 1985, p. 48). Neste sentido, não é gratuito que autores como Lucy (1993) concebam a reflexividade linguística como um poder crucial da linguagem, que a distingue de outros sistemas semióticos. "Em sua forma completa essa propriedade talvez seja única à linguagem humana" (cf. LUCY, 1993, p. 9 [tradução minha]). Neste trabalho, no entanto, parto da reelaboração do conceito por Borillo (1985) e valho-me dos trabalhos de Risso e Jubran (1998), Risso (1999), como veremos.
}

REZENDE - Referenciação metadiscursiva... 
comunicação. "Todos estes fatores poderiam ser objeto de uma menção ou de uma glosa e fazer parte neste caso do que chama chamamos de metadiscurso" (BORILLO, 1985, p. 48).

Vejamos os excertos 1 e 2 a seguir. Sua leitura é imprescindível para a compreensão de toda a obra e do lugar da referenciação metadiscursiva em seu acabamento de estrutura composicional:

\section{Excerto 1 (HATOUM, 1989, final do Cap. 8, p. 165-166)}

O teu presságio me deu trabalho. Gravei várias fitas, enchi de anotações uma dezena de cadernos, mas fui incapaz de ordenar coisa com coisa. Confesso que as tentativas foram inúmeras e todas exaustivas, mas ao final de cada passagem, de cada depoimento, tudo se embaralhava em desconexas constelações de episódios, rumores de todos os cantos, fatos medíocres, datas e dados em abundância. Quando conseguia organizar os episódios em desordem ou encadear vozes, então surgia uma lacuna onde habitavam o esquecimento e a hesitação: um espaço morto que minava a sequência de ideias. E isso me alijava do ofício necessário e talvez imperativo que é o de ordenar o relato, para não deixá-lo suspenso, à deriva, modulado pelo acaso [...].

Este fragmento é um recorte das duas últimas páginas da obra, em que a narradora explica ao irmão como procedeu para elaborar seu relato. Todos os segmentos textuais em negrito e itálico do excerto 1 acima são fragmentos de referenciação metadiscursiva ${ }^{5}$. A ação de referir na/com/pela língua pode realizar-se por meio de predicações ou por meio da construção de expressões nominais (cf. KOCH, 2002). No excerto 1, observamos, por exemplo, nas predicações "gravar, anotar $e$ ordenar" a referência às ações que compreendem a própria condição

\footnotetext{
${ }^{5}$ Jubran (2009) defende que a referenciação metadiscursiva possui a especificidade de não introduzir tópico. Ao contrário da "referenciação tópica", a metadiscursiva ocupa-se justamente do voltar-se do texto, e de seu processamento, sobre si, e dos movimentos interacionais que presidem toda interação verbal, seja ela oral ou escrita. Não partilhamos desta posição. A referenciação metadiscursiva pode também ser referenciação tópica. O Relato... é um contraexemplo muito vívido disso, vide os excertos 1 e 2 aqui recortados. Neles, referir o próprio processo de escrita da obra é referir a ela, topicalizá-la. Não há como distinguir estes dois processos nas páginas finais do Relato... e em muitas passagens ao longo da obra.
} 
material da comunicação para sua elaboração discursiva. Há aí a patente preocupação da narradora em estabelecer um conjunto de ações mais gerais que embasam a sua produção textual. O Relato... só será levado a cabo se histórias forem coletadas (gravar), transcritas e/ou reescritas (anotar) e ordenadas sob a forma de uma narrativa articulada, dotada de unidade de sentido. A narradora, num movimento autorreflexivo, refere ao próprio processo de composição de seu texto, introduzindo a explicação de como o conduziu.

Ato contínuo, e ainda assente nos postulados de Borillo (1985), percebemos que a narradora, também por predicação metadiscursiva, faz referência à condição enunciativa de seus discurso, a contingência: "então surgia uma lacuna onde habitavam o esquecimento e a hesitação". Essa predicação metadiscursiva, em especial, é reveladora da consciência da narradora de que a escrita da memória em sua carta ao irmão possa ter sido também invenção. Novamente, a narradora, em outro movimento autorreflexivo, se refere metadiscursivamente ao processo de composição de seu texto.

Risso e Jubran (1998, p. 228) explicam que o metadiscurso se dá na forma de um "jogo multiplano" na medida em que os elementos da "mise en scène enunciativa", como os exemplificados no excerto 1 acima, também se constituem em objeto de uma menção ou de uma glosa caracterizadora do metadiscurso, seja voltando-se para o texto per se, seja acentuando aspectos interacionais atinentes à formulação do texto em questão. Enunciados metadiscursivos caracterizam-se como procedimentos verbais que sinalizam a "introjeção da instância da enunciação na estrutura dos enunciados textuais", estabelecendo uma integração entre enunciado e enunciação. Assim,

operando no âmbito da atividade enunciativa, como formas de gestão da produção verbal desencadeadas pelo locutor no processamento formulativo do texto, o metadiscurso peculiarizase por estampar, na superfície dos enunciados, um movimento auto-reflexivo que faz o discurso dobrar-se sobre si mesmo, instituindo-se enquanto discurso para referenciar o próprio "fazer" discursivo (RISSO, 1999, p. 204). 
Veja-se, a seguir, o excerto 2, que finaliza o Relato..., quando esse dobrar-se da escrita da obra sobre si mesma, referenciando o seu próprio fazer discursivo, discute aspectos da própria criação literária. É quando o texto do Relato... então se revela como carta e também como romance. Nele são combinados procedimentos de referenciação por predicação com o emprego de expressões nominais de caráter metadiscursivo:

Excerto 2 (HATOUM, 1989, final do Cap. 8, p. 165166) continuação do anterior Quando conseguia organizar os episódios em desordem ou encadear vozes, então surgia uma lacuna onde habitavam o esquecimento e a hesitação: um espaço morto que minava a sequência de ideias. E isso me alijava do ofício necessário e talvez imperativo que é o de ordenar o relato, para não deixá-lo suspenso, à deriva, modulado pelo acaso [...].

Excerto 2 (HATOUM, 1989, final do Cap. 8, p. 165166) continuação do anterior Quando conseguia organizar os episódios em desordem ou encadear vozes, então surgia uma lacuna onde habitavam o esquecimento e a hesitação: um espaço morto que minava a sequência de ideias. E isso me alijava do ofício necessário e talvez imperativo que é o de ordenar o relato, para não deixá-lo suspenso, à deriva, modulado pelo acaso [...].

$[\cdots]$

Também me deparei com um outro problema: como transcrever [p. 166] a fala engrolada de uns e o sotaque de outros? Tantas confidências de várias pessoas em tão poucos dias ressoavam como um coral de vozes dispersas. Restava então recorrer $\dot{\boldsymbol{a}}$ minha própria voz, que planaria como um pássaro gigantesco e frágil sobre as outras vozes [...] tudo o que era audível e visível passou a ser norteado por uma única voz [...] Para te revelar (numa carta que seria a compilação abreviada de uma vida) que Emilie se foi para sempre, comecei a imaginar com os olhos da memória as passagens da infância, as cantigas, os convívios, a fala dos outros, a nossa gargalhada ao escutar o idioma híbrido que Emilie inventava todos os dias. 
Era como se eu tentasse sussurrar no teu ouvido a melodia de uma canção sequestrada, e que, pouco a pouco, notas esparsas e frases sincopadas moldavam e modulavam a melodia perdida.

Expressões nominais são recursos textual-discursivos empregados para a ativação e/ou recategorização de objetos de discurso na cadeia referencial de um texto. Podem também atuar na orientação argumentativa do texto e na construção de ponto de vista do locutor (cf. $\mathrm{KOCH}, 2004)^{6}$. Como recursos da estratégia de referenciação textual, também podem ter natureza metadiscursiva. No excerto 2 acima, a expressão nominal definida "oficio necessário e talvez imperativo que é o de ordenar o relato", por exemplo, apresenta caráter metadiscursivo. A predicação "ordenar" é recategorizada em um nome - "ofício" - que, para a narradora, significa deter um saber-fazer. Essa expressão nominal definida metadiscursiva refere a escrita da obra como um fato enunciativo. Ela auxilia a evidenciar metadiscursivamente a preocupação da narradora vis à vis o acabamento de estrutura composicional do texto.

Não apenas ela. Para além do "ofício necessário" da organização de fatos e episódios, o problema da condução narrativa se faz notório. A busca por uma vOz narrativa, por sua própria voz, é a tentativa de melhor harmonizar a comunicação com o irmão. A narradora volta a valer-se de uma predicação metadiscursiva ("recorrer à minha própria vOz"). Mas é com as duas expressões nominais metadiscursivas ao final do excerto que ela mostra ciência da "dimensão social dos processos linguísticos” (cf. MORATO, 2005, p. 245). Afinal, pela rotulação metadiscursiva "numa carta que seria a compilação abreviada de uma vida" a narradora não apenas define e denomina o gênero discursivo da interação entre ela e o irmão. Ela estabelece o que o gênero pode/é capaz de comunicar, sua função enquanto texto. Já por meio da expressão nominal definida "a melodia de uma canção sequestrada", ela agora define o que é seu discurso narrativo para o irmão, de como é composto por outras práticas de linguagem, "as cantigas, os convívios, a fala dos outros".

\footnotetext{
${ }^{6}$ Remeto o/a leitor/a aos trabalhos de Koch (2002) e Cavalcante, Rodrigues e Ciulla (2003) para uma visada detalhada acerca da estrutura e das funções de diferentes expressões nominais.
}

REZENDE - Referenciação metadiscursiva... 
Em suma, ao comentar sobre aspectos da macroestrutura textual (conteúdos globais), da composição interna e das funções textuais do gênero carta, a narradora do Relato... evidencia uma competência metagenérica (cf. BENTES; KOCH; NOGUEIRA, 2003). À obra não escaparão manifestações metadiscursivas dessa reflexividade sobre os processos que estão na base de sua produção textual.

\section{REFERENCIAÇÃO METADISCURSIVA NA CARTA PESSOAL REPRESENTADA NO ROMANCE}

Voltemos a Barton e Hall (2000). Segundo explicam os autores, porque expressa forte direcionamento comunicativo entre duas partes, e porque esse direcionamento é desenvolvido no interior de uma relação específica segundo uma circunstância também assaz específica - como visto acima no excerto 1 , fragmento do Relato... -, a carta pessoal resulta em um espaço de interação social dotado de uma força que pode suprir, com efeito, a presença imediata dos atores que a interação face a face contém, justamente porque é capaz de trazer consigo aspectos dessa interação: um "eu" que fala em um "aqui agora" e que convoca "você". Não são poucas no Relato... as passagens em que a narradora destaca a ancoragem da sua escrita no interior da situação comunicativa entre ela e o irmão (ela, em Manaus; ele, em Barcelona). Se é constitutivo ao gênero carta indicar procedimentos de ancoragem de sua construção, no Relato... a manifestação característica de traços de escritura epistolar se manifesta, logo no início do livro, por meio de um recurso interativo, a saber, a invocação da pessoa do irmão por meio da lembrança de sua figura:

[p. 12] Antes de sair para reencontrar Emilie, imaginei como estarias em Barcelona, entre a Sagrada Família e o Mediterrâneo, talvez sentado em algum banco da praça do Diamante, quem sabe se também pensando em mim, na minha passagem pelo espaço da nossa infância: cidade imaginária, fundada numa manhã de 1954... (HATOUM, 1989, Cap. 1, p. 12)

Neste fragmento observamos que o irmão-interlocutor é convocado por sua irmã a assumir um papel discursivo na interação de 
ambos, o do leitor que, como ela, também poderia pôr-se a pensar na sua interlocutora, enquanto ela dá a partida para realizar a sua busca por Emilie. Ou seja, é estabelecido um jogo interativo de "enquanto eu penso em você porque estou aqui na cidade de nossa infância, você deve quiçá estar pensando em mim"; um cenário comunicativo que evidencia com clareza que a missiva a ser escrita (a obra final que lemos) toma o irmão logo de início como seu único destinatário. O direcionamento desta carta de memórias é total e exclusivamente focado nele. Assim, é centrado no enquadre interacional de um "eu" que fala em um "aqui agora" e que convoca "você", o qual Barton e Hall (2000) caracterizam como inerente à carta pessoal, que a irmã-narradora abrirá uma de suas memórias mais profundas (e dolorosas, como ela mesma revelará): a morte de Soraya Ângela. Dessa lembrança o irmão participa, no plano enunciativo da obra como um todo, como instância coprodutora do texto:

Tu ainda engatinhavas naquele natal de 54 e Soraya Ângela era a minha companheira. Quase sempre choramingavas quando ela aparecia (HATOUM, 1989, Cap. 1, p. 13)

Repare-se logo de saída neste fragmento como há tanto um movimento interativo quanto um movimento ideacional, ambos promovidos pela narradora, e que se dão concomitantemente: a centração sobre o referente do tópico discursivo a ser desenvolvido, "Soraya Ângela" vem, já em sua ativação no discurso, acompanhada da referência a essa instância coprodutora do texto, ele, o irmão: “Tu ainda engatinhavas e Soraya Ângela era a minha companheira". Feita então a convocação interacional, e estabelecida a centração em um tópico, observamos menções a ações do irmão, de quando de sua convivência com Soraya: "engatinhavas"; "choramingavas". Elas funcionam como traços de uma dialogicidade mostrada que atuam como canais de entrada na/para a elaboração de uma memória que ao longo da obra será construída compartilhadamente.

A memória é, com efeito, uma prática social. Bosi (1999) explica que o lembrar para o outro é sempre um lembrar com o outro. Cada memória individual é um ângulo de observação da memória coletiva. $\mathrm{O}$ 
passado do grupo é o passado do indivíduo, embora seja o indivíduo quem retém detalhes, pessoas e objetos que lhe são "significativos dentro do tesouro comum" (cf. BOSI, 1999, p. 411). Se os gêneros discursivos são quadros de orientação para a ação e interação na/pela linguagem dos sujeitos com o mundo (cf. MARCUSCHI, 2008; HANKS, 2008), isso implica afirmar que a carta pessoal memorialística é um gênero cuja produção também possui, como todo gênero discursivo, uma dimensão social:

Porque a socialidade dos textos é sempre uma questão de compreensão social implícita incorporada ao nosso reconhecimento dos gêneros [discursivos] que moldam a atividade comunicativa é que a leitura e a escrita têm regularmente sido tomadas de forma equivocada como processos autônomos de apenas forma e sentido, separados de circunstâncias sociais, relações sociais e da ação. As cartas, comparadas a outros gêneros, podem parecer modestas, porque são tão explicitamente ligadas a relações sociais privadas de escritores e leitores específicos, mas isso significa apenas que elas revelam-nos tão clara e explicitamente a socialidade que é parte de toda escrita ${ }^{7}$ (BAZERMAN, 2000, p. 27).

Com base no que afirma Bazerman acima, os excertos 1 e 2 vistos por nós expressam com vigor a natureza íntima do texto: é uma carta de memórias, de uma mulher para seu irmão, em que ambos buscam compreender seu passado comum. Ao mesmo tempo, essa relação íntima está incorporada a um contexto social mais amplo, o da adoção de crianças órfãs por imigrantes libaneses. A questão é que esse esforço memorialístico não é individual, mas conjunto. É de ambos. $\mathrm{E}$ isso lhe configura também um caráter social, haja vista que o lembrar para o

\footnotetext{
7 No original: "Because the sociality of texts is often a matter of implicit social understanding embedded in our recognition of genres that shape communicative activity, reading and writing have regularly been mistaken as autonomous processes of pure form and meaning, separate from social circumstances, relationships, and action. Letters, compared to other genres, may appear humble, because they are so overtly tied to particular social relations of particular writers and readers, but that only means they reveal to us so clearly and explicitly the sociality that is part of all writing" (cf. BAZERMAN, 2000, p. 27).
} 
outro é sempre um lembrar com o outro no empenho de fazer da(s) memória(s) individual(is) uma memória comum ao grupo.

Assente ainda no que afirma Bazerman, pensar o processo de escrita da carta pessoal de cunho rememorativo requer que entendamos todos os recursos metadiscursivos referentes ao ato de lembrar como incorporados a essa estrutura: "vou lembrar para e com você, meu irmão, aqui neste texto que te escrevo". O lembrar é, neste gênero textual, e no Relato..., em especial, uma ação dialógica que não prescinde da referenciação metadiscursiva. Essa referenciação metadiscursiva que constrói uma memória conjunta na obra atua na própria condução do enredo.

Para defender esta afirmação, e na esteira deste primeiro aspecto de caracterização da "socialidade" da escrita da carta pessoal tal como postula Bazerman, outro aspecto caracterizador dessa socialidade é a própria temporalidade característica do gênero. Hanks (1996, p. 278) estabelece uma distinção entre temporalização e historicização dos gêneros discursivos. A temporalização é inerente ao próprio gênero enquanto evento discursivo que se desenvolve numa dada cronologia. É o seu tempo interno, seu presente que se desenvolve a cada momento e que estabelece uma correlação entre este presente e um campo discursivo mais amplo. Já a historicização do gênero discursivo é aquela temporalidade que o reifica, tornando-o um objeto passível de ser representado, avaliado e/ou reportado.

A produção textual epistolar não se resume a apenas um artefato textual: uma única carta enviada pelo emissor a seu leitor. Ela pode efetivar-se - e no mais das vezes o faz - como troca. A caracterização do gênero epistolar prevê a possibilidade de circulação de mais de um texto e sua recepção em contextos variados. A depender do grau de intimidade entre remetente e destinatário, e a profundidade e/ou urgência do(s) tema(s) de que trata, a carta pessoal se concretiza mais como uma série, uma sequência de epístolas, do que como um exemplar apenas. Sua temporalização pode ser observada tanto a um nível "macro" - o tempo de duração da sequência, isto é, da própria troca epistolar como um todo - quanto a um nível "micro", o da duração da escrita de cada uma delas. $\mathrm{E}$, neste sentido, é-lhe constitutiva a retomada constante de temas e/ou aspectos seus de que os missivistas precisam falar. De sorte que neste processo os sujeitos acabam por "historicizá-lo", no sentido proposto 
por Hanks (1996), valendo-se, para tanto, de expedientes de referenciação metadiscursivos que incidem sobre o discurso de seu interlocutor.

Vejamos o episódio da morte da menina Soraya Ângela, por atropelamento, para compreender o lugar da referenciação metadiscursiva na construção da memória compartilhada e na caracterização do gênero carta pessoal memorialística. A imagem do corpo de Soraya ato contínuo ao atropelamento é uma das imagens, segundo afirmará a narradora, mais dolorosas de sua infância:

\section{Excerto 3 (HATOUM, 1989, Cap. 1, p. 21; 22)}

Sob a luz intensa do sol todos pareciam de bronze, apenas destoavam o florido da saia de Emilie e a mancha vermelha que ainda se alastrava ao longo do lençol transformado em casulo, a cabeça tal um gorro grená, ou um vermelho mais intenso, mais concentrado, como se a cor tivesse explodido ali, numa das extremidades do corpo.

Foi uma das imagens mais dolorosas da minha infância; talvez por isso tenha insistido em evocá-la em duas ou três cartas que te escrevi; na tua resposta me chamavas de privilegiada porque esses eventos haviam acontecido quando eu já podia, bem ou mal, fixá-los na memória. Numa das cartas que me enviaste, escreveste algo assim: "A vida começa verdadeiramente com a memória, e naquela manhã ensolarada e fatídica, tu te lembras perfeitamente das quatro pulseiras de ouro no braço direito de Emilie e do seu vestido bordado com flores; que privilégio, o de poder recordar tudo isso, e eu? [...] não participava sequer do estarrecimento, da tristeza dos outros, lembro apenas que Soraya Ângela existia [...] Soube, por ti, que eu quase testemunhara sua morte; vã testemunha, onde eu estava naquela manhã?"

Nota-se no excerto 3 que a memória traumática da narradora referente ao acontecimento (a luz do sol, a saia de Emilie, o corpo no lençol) está condensada na expressão nominal rotuladora "uma das imagens mais dolorosas da minha infância”. O rótulo é um recurso de coesão lexical que se caracteriza como um elemento nominal 
inerentemente não específico cujo significado específico no discurso necessita ser precisamente decifrado para, então, tornar-se um objeto de discurso. Observa-se no excerto que na interação entre os irmãos esse novo objeto de discurso, "uma das imagens mais dolorosas da minha infância" está associado à expressão nominal metadiscursiva "duas ou três cartas que te escrevi". A expressão refere a própria interação entre os irmãos. Ela glosa sobre a postura da narradora enquanto copartícipe da interação por meio de cartas com o irmão, revelando que o gênero epistolar se concretiza, com efeito, por meio de trocas, atividade de mão dupla que pode ser metadiscursivamente avaliada no curso de seu processo.

Não apenas a expressão nominal metadiscursiva "duas ou três cartas...", mas também as expressões nominais "tua resposta" e "Numa das cartas que me enviaste", que lhe são subsequentes, também referem a interação epistolar estabelecida entre os irmãos e o próprio gênero discursivo em que ela se concretiza. Além delas, a predicação metadiscursiva "escreveste algo assim" retoma um fragmento dessa interação, promovendo a articulação de fragmentos de uma carta anterior para compor o texto final endereçado ao irmão (que é o próprio Relato...). Quando retoma o trecho de uma carta do irmão a narradora está historicizando (no sentido proposto por Hanks) a sua própria, tornandoa ela também um objeto passível de ser futuramente representado, avaliado e/ou reportado em uma outra eventual troca epistolar. Tanto o é que no segundo segmento metadiscursivo do excerto 3, "na tua resposta...", observamos que a narradora seleciona uma expressão referencial - promovendo uma rotulação metadiscursiva retrospectiva cujo núcleo ("resposta") denota a escrita do irmão como um ato ilocucionário (cf. JUBRAN, 2003, p. 97) característico da dinâmica da própria prática epistolar em que os sujeitos propõem/perguntam tópicos para obterem futuras respostas. Vale anotar também que a expressão "algo assim" a seguir ao verbo escreveste ("escreveste algo assim") atua como uma espécie de elemento prefaciador do fragmento textual atribuído ao irmão, ao preanunciar como teria sido, segundo a rememoração da irmã, seu discurso.

Em todo o Relato... não é dada ao leitor a sequência cronológica de troca de cartas entre os irmãos. Nota-se, no entanto, que uma dessas trocas, quando revelada nos/pelos segmentos metadiscursivos como no 
excerto 3, atua como um mecanismo de operacionalização da progressão textual da obra. As cartas do irmão à irmã-narradora não são apenas mencionadas ou aludidas, mas retomadas sob a forma de discurso direto, introduzido por expediente metadiscursivo que, assim, colabora na condução da narrativa.

Tomemos então, do excerto 3 acima, a primeira e a última frases do fragmento da carta que o irmão enviou à irmã. Por meio da primeira, "A vida começa verdadeiramente com a memória", ele demonstra compreender que o viver está intimamente atrelado ao poder lembrar; já na última, quando afirma "vã testemunha, onde eu estava naquela manhã?", ele demonstra indignação de então não poder "estar vivo" quando do acontecimento, por não conseguir lembrá-lo. Ora, quando então retornamos às construções metadiscursivas na escrita da narradora, constatamos que ela colmata esse vazio entre a constatação do irmão e sua indignação. A rotulação metadiscursiva do discurso do irmão, retomando-o, incorporando-o ao seu, destaca-se nesse processo. Tanto o é que a pergunta ao fim da carta do irmão é o mote para a abertura, de forma dialógico-responsiva, de um novo tópico, contribuindo para a progressão textual da obra:

"Soube, por ti, que eu quase testemunhara sua morte; vã testemunha, onde eu estava naquela manhã?"

Passaste o dia falando dos peixes e dos animais que tinhas visto no mercado, sem entender o alvoroço, a consternação que reinava na casa. Vestias uma camisolinha de cambraia de linho, daquelas em que Emilie bordava duas cabeças de cavalo, ou melhor, bordava o contorno da cabeça e a crina, e o que sobrava pertencia ao tecido transparente, elegia à tua pele. Tu aparecias aos outros vestido assim: a camisola bordada caindo até o joelho, com as iniciais do teu nome bordadas com letras góticas. Era uma incongruência que te cobria da cabeça aos pés: botas, bordados, meias compridas, extravagâncias de Emilie. (HATOUM, 1989, Cap. 1, p. 22)

No fragmento acima vemos, tal como no excerto 3, que o discurso reportado do irmão atua de forma a encetar a progressão do 
texto da narradora, na medida em que ela responde na presente carta a um ato ilocucionário do irmão, uma pergunta, abrindo assim um novo tópico discursivo no fio narrativo do Relato....

Este mesmo procedimento de retomada do discurso do irmão por meio de discurso direto citado se intensifica em um capítulo estrutural da obra, o capítulo sexto. Só que a reclamação do irmão por "não conseguir lembrar" experimentará uma inversão de papéis entre ele e sua irmã. A irmã-narradora não deixa de continuar seu procedimento de invocar uma memória; no entanto, a memória agora a ser invocada não será apenas a sua própria, mas a do irmão: ela lembra dos relatos, alusões e lembranças dele nas cartas que ele lhe escreveu. Este fato reitera, uma vez mais, o funcionamento da própria dinâmica da troca epistolar pessoal. As memórias do irmão também são articuladas neste relato que lemos. E aqui, novamente, a referenciação metadiscursiva atua na estruturação dessa articulação. disso.

O episódio da travessia do rio Negro a barco é representativo

Após caminhar pela cidade, quando a narradora-personagem observa, do barco em que atravessa o rio Negro, a cidade de Manaus, ela se dá conta de que ao longe a cidade em nada se assemelha àquela por que ela própria caminhara. Ao escrever sobre esse fato (ao longo da própria travessia a barco), o texto do irmão é usado como argumento afetivo que ilumina a transformação a que a cidade vai se submetendo à medida que a narradora se aproxima dela:

\section{Excerto 4 (HATOUM, 1989, Cap. 6, p. 123-124)}

Essa passagem de uma paisagem difusa a um horizonte ondulante de ardósia, interrompido por esparsas torres de vidro, pareceu-me tão lenta quanto a travessia, como se eu tivesse ficado muito tempo na canoa. Tive a impressão de que remar era um gesto inútil: era permanecer indefinidamente no meio do rio. Durante a travessia, estes dois verbos no infinitivo anulavam a oposição entre movimento e imobilidade. E à medida que me aproximava do porto, pensava no que me dizias sempre: "Uma cidade não é a mesma cidade se vista de longe, da água: não é sequer cidade: falta-lhe perspectiva, profundidade, traçado, 
e sobretudo presença humana, o espaço vivo da cidade. Talvez seja um plano, uma rampa, ou vários planos e rampas que formam ângulos imprecisos com a superfície aquática”

Demorou, na verdade, para atracarmos à beira do cais.

Similarmente ao que vimos em outros fragmentos, a reflexão da narradora sobre sua própria escrita é articulada ao discurso de seu irmão também por meio de uma predicação metadiscursiva (marcada em negrito com itálico no excerto): "pensava no que me dizias sempre". Pois a narradora se vale de um verbo referenciador de atividade discursiva (“dizias"), que retoma um fragmento de carta do irmão, reportada sob a forma de discurso direto, que nos remete a um outro momento da comunicação entre eles, momento no qual é o irmão quem demonstrava possuir um conhecimento específico. Aqui, o fragmento de carta do irmão que compõe a tessitura do Relato..., articulado pelo procedimento metadiscursivo, revela um movimento contrário: agora é ela que precisa dele, de seu conhecimento, para seguir redigindo o relato-memória que se propôs a fazer.

Não só de seu conhecimento, a irmã demonstra precisar da memória do irmão. Isso é notório quando o tópico do diálogo epistolar entre eles passa a ser Dorner, fotógrafo alemão e amigo da família de imigrantes libaneses que adotou a narradora e o irmão.

Em uma conversa com Dorner no interior de uma igreja em razão da tempestade que se abate sobre Manaus, o diálogo que travam a narradora e o fotógrafo alemão também fá-la glosar, metadiscursivamente, constantemente sobre a escrita do irmão. Ali na igreja, "diante de uma gruta incrustrada à direita da nave central", num "recanto iluminado por chumaços de velas brancas, enormes, que derretiam entre diversos tocos de velas acesas" (p. 130), ela se dá conta de um Dorner com um ar um tanto melancólico, com "a expressão fria de quem definha” (p. 133). Dorner foi uma espécie de preceptor informal do irmão caçula da narradora. Deu-lhe lições de alemão "proferidas diante de um mapa enrugado, pregado na parede úmida do porão" (p. 133) - ou "sobre fotografia, sobre Leipzig, sobre Berlim vista 
por Kleist, sobre a guerra e os alemães perseguidos e humilhados até mesmo em Manaus" (p. 133).

Dorner era, e continua sendo, assunto nas cartas trocadas entre os irmãos. Observemos os excertos 5 e 6 abaixo:

\section{Excerto 5 (HATOUM, 1989, Cap. 6, p. 133)}

Ao acabar a frase permaneceu impassível, e o seu rosto recuperou o mesmo ar melancólico, a expressão sombria de alguém que definha. Mais uma vez me lembrei de ti, das tuas alusões ao outro Dorner que pouco conheci, te dando lições de alemão ou falando sobre fotografia [...]

\section{Excerto 6 (HATOUM, 1989, Cap. 6, p. 135)}

Nas tuas raras alusões a Dorner, falavas não de um ser humano, e sim de uma "personagem misteriosa", de um "náufrago enigmático que o acaso havia lançado à confluência de dois grandes rios, como uma gota de orvalho surge imperceptivelmente na pele de uma pétala escura num momento qualquer da noite". Tu e a tua mania de fazer do mundo e dos homens uma mentira, de inventariar ilusões no teu refúgio na rua Montseny, ou nas sórdidas entranhas do "Barrio Chino", no coração noturno de Barcelona, para poder justificar que a distância é um antídoto contra o real e o mundo visível. Eu, ao contrário, não podia, nunca pude fugir disso. De tanto me enfronhar na realidade, fui parar onde tu sabes: entre as quatro muralhas do inferno [itálico acrescentado].

Nota-se que, num primeiro momento, a irmã [excerto 5] faz um comentário metadiscursivo referenciador de um ato ilocucionário do irmão (cf. JUBRAN, 2003, p. 97) como “alusões”, por meio da expressão nominal metadiscursiva "tuas alusões ao outro Dorner".

Num segundo momento [excerto 6], ela opera uma modificação da expressão nominal: "raras alusões". A adição do modificador "raras" na rotulação metadiscursiva "tuas alusões" é indicativa de que Dorner parece ser um assunto, se não "tabu”, um tanto enviesado entre os 
irmãos. Não é possível, porém, saber o porquê disso. Dentre tantos outros, este é mais um dos conflitos não resolvidos que o Relato... guarda dentro de si. Se "alusão" define-se como uma referência vaga, feita de maneira indireta, ou ainda como uma "avaliação indireta de uma pessoa ou fato pela citação de algo que possa lembrá-lo" (cf. HOUAISS), com efeito, as duas expressões referenciais "personagem misteriosa" e "náufrago enigmático que o acaso..." (e que não são metadiscursivas) empregadas pelo irmão em relação ao personagem Dorner no excerto 6 acima ou possuem um caráter um tanto hiperonímico, e, neste sentido, alusivo, ou configuram uma atitude de falsa especificação, que mais esconde o referente em metáforas do que o revela ("náufrago enigmático que o acaso havia lançado à confluência de dois grandes rios" [trecho em itálico]). À guisa de comparação entre o irmão e sua irmã-narradora, é importante observar como a narradora-personagem constrói uma grande expressão referencial (excerto 7 abaixo [todo o segmento em itálico]) cujo referente é "Dorner":

\section{Excerto 7 (HATOUM, 1989, Cap. 6, p. 134; 135)}

Pensei também em Dorner, esse morador-asceta de uma cidade ilhada, obstinado em passar toda uma vida a proferir lições de filosofia para um público fantasma, obcecado pelo aroma das orquídeas, das ervas com folhas carnosas e das flores andróginas. Ele convivia há muito tempo entre os livros e um mundo vegetal, e era capaz de nomear de cor três mil plantas. Não posso saber se a solidão o dilacerava, se alguma morbidez havia na decisão de fixar-se aqui, escutando a sua própria voz, dialogando com o Outro que é ele mesmo: cumplicidade especular, perversa e frágil. Nas tuas raras alusões a Dorner [...]

Ora, quando comparamos a elaboração de uma expressão nominal que faça referência ao objeto-de-discurso "Dorner" feita pelo irmão e a feita pela irmã, é ela quem se esforça em, ou parece estar mais comprometida com, construir uma referência discursiva sobre $\mathrm{O}$ fotógrafo alemão que seja mais ou menos próxima da história de vida dele no Amazonas (um dado de caráter mais empírico, portanto). 
Voltemos uma vez mais ao excerto 6 acima. Quando observamos a descrição no excerto que ela faz sobre o irmão ("tua mania de faz̧er dos homens uma mentira, de inventariar ilusões"), constatamos ser esta também uma expressão nominal metadiscursiva. Como já afirmado, o metadiscurso se caracteriza pela glosa do texto sobre si próprio ou sobre os elementos do processo de produção textual. No caso em questão, ela avalia - e explicita isso ao irmão - o caráter de artifício da construção do discurso dele, seu interlocutor, num dado momento da interação epistolar entre eles.

O que o excerto 6 fundamentalmente nos mostra é que a irmãnarradora avalia, metadiscursivamente, a postura do irmão pela forma como ele lida com a relação entre a linguagem e o mundo, estabelecendo um vínculo entre essa atitude e um espaço físico de privacidade (a rua Montseny, em Barcelona, é, segundo ela, o "refúgio" do irmão). Nossa leitura é a de que há aqui o fechamento de um ciclo dentro da obra. "Antes de sair para reencontrar Emilie" (p. 12), no início de seu trajeto, portanto, a narradora mentalizara seu irmão ocupando um espaço físico no presente

[p. 12] Antes de sair para reencontrar Emilie, imaginei como estarias em Barcelona, entre a Sagrada Família e o Mediterrâneo, talvez sentado em algum banco da praça do Diamante, quem sabe se também pensando em mim, na minha passagem pelo espaço da nossa infância: cidade imaginária, fundada numa manhã de 1954... (HATOUM, 1989, Cap. 1, p. 12)

talvez em algum "banco da praça do Diamante", em Barcelona. Este é um momento no capitulo primeiro do Relato... no qual um afloramento do passado, que está prestes a principiar, parece, com efeito, combinar-se "com o processo corporal e presente da percepção" - de que fala Bosi (1999, pp.46-47) - da própria narradora, levando-a a pensar no irmão também no presente.

No excerto 6, quando está prestes a completar o trajeto, a narradora retoma a figura do irmão uma vez mais, novamente tentando localizá-lo também naquele mesmo espaço físico do presente, o qual ela agora especifica: ele estaria no seu refúgio, de onde tenta "justificar que a 
distância é um antídoto contra o real e o mundo visível" (p. 135). Chamar Barcelona de "refúgio" não nos parece gratuito da parte da irmã-narradora. À página 134 do Relato... ela afirmara que pensou "na tua [do irmão] repulsa a esta terra [Manaus], na tua decisão corajosa e sofrida de te ausentar por tanto tempo, como se a distância ajudasse a esquecer tudo".

Estas informações são reveladoras de como a cumplicidade entre os irmãos é marcante na obra. Ganha um sentido mais profundo o pedido do irmão, à página 165 da obra, para que ela anotasse tudo o que acontecesse em Manaus. Ele parece não suportar a força "latente e penetrante, oculta e invasora" que uma viagem a Manaus lhe causaria como causou na irmã. Ela, ainda assim, não deixa de ver a decisão do irmão de distanciar-se de Manaus, e do passado, com admiração, como um gesto de coragem.

Fechado este ciclo no capitulo sexto, fecha-se também o da própria escrita, no capitulo oitavo da obra, quando a narradora revela ao irmão como foi sua internação em uma clínica de repouso [excerto 8] - quando tentou redigir uma primeira versão de um relato do passado ao irmão e, finalmente, quando redige a versão final:

\section{Excerto 8 (HATOUM, 1989, Cap. 8, p. 159)}

Lembro-me de que na penúltima carta quiseste saber quando eu ia deixar a clínica, e "sem querer ser indiscreto" me fizeste várias perguntas, e até brincaste: "Não se trata de uma inquisição epistolar". Sei que não era uma carta inquisitória, mas a tua curiosidade exorbitante às vezes me assusta, a ponto de me deixar perplexa e desarmada. O que aconteceu comigo quando morei na clínica? As primeiras semanas vivi imersa na escuridão pacata de um sono contínuo e sem sonhos

\section{Excerto 9 (HATOUM, 1989, Cap. 8, p. 166)}

[...] Na última [carta], ao saber que vinha a Manaus, pedias para que eu anotasse tudo o que fosse possível: "Se algo inusitado acontecer por lá, disseque todos os dados como faria um bom repórter, um estudante de anatomia, ou Stubb, o dissercador de cetáceos"

O teu presságio me deu trabalho. 
Pode-se dizer que os excertos 8 e 9 acima, pertencentes ao capitulo oitavo da obra, repetem todos os procedimentos metadiscursivos oferecendo como que uma espécie de combinação final destes presentes nos capítulos primeiro e sexto do Relato..., que atuam seja na elaboração do discurso memorialístico (porque acentuam a marcação de posição do sujeito como agente do discurso, que se percebe em uma relação intersubjetiva) e de traços interacionais do gênero epistolar, seja também, ainda no que diz respeito à construção do próprio gênero epistolar, na elaboração das tomadas e retomadas, por meio de expressões nominais metadiscursivas que referem ou retomam o discurso do interlocutor, contribuindo no/para o desenvolvimento do enredo do Relato....

\section{CONSIDERAÇÕES FINAIS}

Neste artigo, propus-me a demonstrar que a interação entre os irmãos missivistas do Relato de um certo oriente se constitui sob diferentes maneiras de manifestação metadiscursiva que contribuem (como visto, ora com referências às instâncias coprodutoras do texto, ora por meio de referências à prática epistolar em processo) para a construção do enredo da obra, do texto do Relato... como uma escrita reflexiva.

A reflexividade metadiscursiva de composição do texto, manifesta explicitamente nos fragmentos do capítulo oitavo da obra [excertos 1 e 2], em que a narradora comenta diretamente sobre seu processo de escrita, se desdobra nos excertos que compõem a interação epistolar entre os irmãos em uma reflexividade enunciativa construída numa temporalidade dilatada, pressuposta na obra por alusões da irmã, mas também evidenciada pela incorporação do discurso de seu irmão e de suas condições enunciativas em sua própria construção discursiva. Assim, destacam-se as manifestações cuja incidência é destinada a atuar na progressão textual da obra, munidas, todas elas, de um notório caráter textual-interativo. A distância, seja temporal, seja espacial, não impede um diálogo distendido no tempo; diálogo que, responsivo, retoma, para anuir ou contra-argumentar, a fala do outro; e que, por isso, é rico de 
expedientes metadiscursivos e, na esteira destes, de usos do discurso citado na/para a construção discursiva daquele que escreve.

A análise indica que é possível, e tendo como base as reflexões de Barton e Hall (2000) e Bazerman( 2000), à guisa de conclusão, apontar que o gênero carta pessoal memorialística, quando representado no interior de um romance, "exige" a referenciação metadiscursiva na/para condução do enredo e contribuição da criação da atmosfera memorialística da obra.

\section{REFERÊNCIAS}

BAKHTIN, M. Discourse in the novel. In: HOLQUIST, M. (Org.). The dialogical imagination - four essays. Austin: University of Austin Press, 2004.

BARROS, K. (Org.). Produção textual: interação, processamento, variação. Natal: Editora da UFRN, 1999.

BARTON, D.; HALL, N. Letter writing as social practice. Philadelphia: John Benjamins Publishing, 2000.

BAZERMAN, C. Letters and the social grounding of differentiated genres. In: BARTON, D.; HALL, N. (Orgs.). Letter writing as social practice. Philadelphia: John Benjamins Publishing, 2000.

BENTES, A.C.; KOCH, I.G.; NOGUEIRA, C. Gênero, mídia e recepção: sobre as narrativas televisivas e seus espectadores. Cadernos de Estudos Linguísticos, n. 44, p. 265-282, jan.-jun. 2003.

BORILLO, A. Discours ou metadiscours? DRL AV, n. 32, p. 47-61, 1985.

BOSI, E. Memória e sociedade: lembrança de velhos. São Paulo: Companhia das Letras, 1999.

CAVALCANTE, M; RODRIGUES, B.; CIULLA, A. (Orgs.). Referenciação. São Paulo: Contexto, 2003.

HANKS, W. F. Language and communicative practices. Boulder: Westview, 1996.

. Lingua como prática social: das relações entre língua, cultura e sociedade a partir de Bourdieu e Bakhtin. Organização e tradução Anna Christina Bentes, Renato C. Rezende, Marco Machado. São Paulo: Cortez, 2008. 
HATOUM, M. Relato de um certo oriente. São Paulo: Companhia das letras, 2005 [1989].

JUBRAN, C.C.A.S. O discurso como objeto-de-discurso em expressões nominais anafóricas. Cadernos de Estudos Linguísticos, n. 44, p. 93-103, jan.-jun. 2003. 303, 2009.

. O metadiscurso entre parênteses. Estudos Linguísticos, v. 38, n. 3, p. 293 -

KOCH, I. G. V. Desvendando os segredos do texto. São Paulo: Cortez, 2002. . Introdução à linguística textual. São Paulo: Martins Fontes, 2004.

LUCY, J. Reflexive language and the human disciplines. In: (Org.). Reflexive language: reported speech and metapragmatics. Cambridge: Cambridge University Press, 1993. p. 9-32.

MORATO, E. Metalinguagem e referenciação: a reflexividade enunciativa nas práticas referenciais. In: KOCH, I.; MORATO, E.; BENTES, A. (Orgs.). Referenciação e discurso. São Paulo: Contexto, 2005.

RISSO, M.; JUBRAN, C. O discurso auto-reflexivo: processamento metadiscursivo do texto. D.E.L.TA., v. 14, p. 227-242, 1998.

RISSO, M. A propriedade auto-reflexiva do metadiscurso. In: BARROS, K. (Org.). Produção textual: interação, processamento, variação. Natal: Editora da UFRN, 1999.

Recebido em: 30/07/12. Aprovado em: 25/10/12.

Title: Metadiscursive reference in personal letter within the novel: a case study

Author: Renato Cabral Rezende

Abstract: This work aims at analyzing metadiscursive reference as an inherent linguistic phenomenon in the personal letter when this genre is represented within another discourse genre, the novel. One of the main features of the personal letter is that it is not achieved in one textual artifact. On the contrary, this genre allows itself a long term duration by means of more than one textual artifact due to the exchange of letters between subjects. Within the epistolary novel, it is letter exchange that acts upon the plot. This work aims at analyzing samples of metadiscursive reference employed by the narrator to keep her interlocutor (the narrator's own brother) abreast of the Lebanese family that adopted them. One concludes that the personal letter as a discourse genre, when represented within a novel, "demands" metadiscursive reference so that both plot and an atmosphere of reminiscence in the novel may be created.

Keywords: Reference. Metadiscourse. Letter. Novel. Milton Hatoum. 


\section{8}

Titulo: Referenciación metadiscursiva en el género carta personal en el interior de la novela: un estudio de caso

\section{Autor: Renato Cabral Rezende}

Resumen: Este trabajo pretende discutir la referenciación metadiscursiva como fenómeno inherente al género carta personal cuando representado en el interior de otro género discursivo, La novela. La carta personal tiene como una de sus características el no agotamiento en un único artefacto textual. El género posibilita a sí propio una duración larga, alimentada por el cambio epistolar entre los interactuantes. En la novela epistolar, el cambio de cartas promueve el paso del tiempo, la realización de acciones y la construcción del relato. El corpus de este trabajo es la obra Relato de un cierto oriente, de Milton Hatoum. Analizaremos ejemplos de referenciación metadiscursiva que utiliza la narradora-misivista para informarle a su interlocutor, su bermano, sobre la familia de inmigrantes libaneses que los adoptó. Se apunta como conclusión que el género carta, cuando representado en el interior de una novela, "exige" la referenciación metadiscursiva en la/para conducción del relato y en la creación de la atmósfera memorialistica de la obra.

Palabras-clave: Referenciación. Metadiscurso. Género epistolar. Novela. Milton Hatoum. 